\title{
Gender, work orientations and job satisfaction
}

Article

Accepted Version

Zou, M. (2015) Gender, work orientations and job satisfaction. Work, Employment and Society, 29 (1). pp. 3-22. ISSN 09500170 doi: https://doi.org/10.1177/0950017014559267 Available at https://centaur.reading.ac.uk/82776/

It is advisable to refer to the publisher's version if you intend to cite from the work. See Guidance on citing.

To link to this article DOI: http://dx.doi.org/10.1177/0950017014559267

Publisher: Sage

All outputs in CentAUR are protected by Intellectual Property Rights law, including copyright law. Copyright and IPR is retained by the creators or other copyright holders. Terms and conditions for use of this material are defined in the End User Agreement.

\section{www.reading.ac.uk/centaur}

\section{CentAUR}

Central Archive at the University of Reading

Reading's research outputs online 


\title{
Gender, work orientations and job satisfaction
}

\author{
Min Zou
}

\begin{abstract}
This article studies the gender gap in job satisfaction and argues that the observed gender difference is a consequence of the heterogeneity in work orientations between men and women. Using data from the 2006 Skills Survey, the analysis yields three major findings. The first shows that women, either in full-time or part-time employment, report significantly higher levels of job satisfaction than men. Secondly, work orientations are closely associated with one's job satisfaction and their relationships vary significantly across men, women full-time and part-time workers. Finally, and most importantly, the observed gender satisfaction differential is eliminated once work orientations are taken into consideration.
\end{abstract}

Key words: Gender, job satisfaction, multiple imputation, work orientations

\section{Introduction}

In the job satisfaction literature, a large number of studies have found that female workers reported higher levels of job satisfaction than their male counterparts (e.g., 
Brown et al., 1983; Clark, 1997; Curtice, 1993; Meng, 1990; Sloane and Williams, 2000; Sousa-Poza and Sousa-Poza, 2003; Townsend, 1979). However, this is a rather counter-intuitive finding as women's relatively disadvantaged positions in the labour market have been widely documented. Hakim (1991) has found, for example, although women full-timers are similar to men, women part-timers are happier with their job than men despite their poor quality work and employment conditions. Hakim termed this puzzle the 'grateful slaves' paradox.

A number of explanations have been developed to approach this paradox. It has been argued that, for example, the gender gap in job satisfaction may be caused by the systematic differences in job characterises that women and men have experienced (Clark, 1997; Dex, 1988). A second hypothesis is that the gender job satisfaction differential reflects different views between men and women regarding what is important in a job (Clark, 1997). More recently, economists argue that women may have lower expectations of income compared to men (Clark, 1997; Sloane and Williams, 2000). These hypotheses have gained some empirical support, but none of them provide a complete account for the observed gender gap in job satisfaction.

This article aims to explore gender difference in job satisfaction from a work orientations perspective. Work orientations refer to one's evaluation of the importance associated with different rewards from employment (Bennett, 1974; Doorewaard et al., 2004). Previous research finds that it is a useful concept to help understand the differences in work-related attitudes across different groups of workers (George and Jones, 1997; Goldthorpe et al., 1968). However, there has been limited effort to approach the 'grateful slaves' paradox from this perspective. This article attempts to 
bridge this gap by using data from the 2006 UK Skills Survey to empirically explore the relationships between work orientations and gender job satisfaction differentials.

The remainder of the article is organised as follows. The following section will review previous research and develop a work orientations approach to address the gender differential in job satisfaction. After that, data sources, measures and analytical strategies of the empirical investigations will be discussed and the model estimation results will be presented. Finally the concluding remarks will be offered.

\section{Previous research}

There is a long standing paradox in women's employment. On the one hand, a substantial body of research has documented gender inequality in the labour market and urged for changes in policies to improve women's working conditions (Anderson, 2001; Darity and Mason, 1998; Duncan and Loretto, 2004). On the other hand, studies on work attitudes have consistently found that female workers' self-reported job satisfaction is higher than that of their male counterparts. It has been suggested that the gender gap in job satisfaction is caused by the systematic differences in occupations and work contents experienced by women and men. Controlling for such differences should therefore eliminate much of this gender gap (Dex, 1988). The empirical evidence does not, however, support this view (Clark, 1997; Sloane and Williams, 2000; Sousa-Poza and Sousa-Poza, 2003). A recent study has shown that in the UK, the gender job satisfaction differential remains robust even after controlling 
for a wide range of individual and organisational characteristics (Asadullah and Fernández, 2008).

While it is helpful to look into job and personal characteristics to understand gender difference in job satisfaction, some researchers suggest that this approach overlooks the impact of work orientations individuals possess and this holds the key to tackling some unanswered questions such as the 'grateful slaves' paradox (Clark, 1997; Hakim, 2000). Although different conceptualisations exist (see Rose (2007) for a comprehensive review), a common view is that work orientations reflect individuals' prioritisations of different rewards from employment which shape their work attitudes and behaviour by providing meanings to their responses to work situations (Goldthorpe et al., 1968). ${ }^{1}$ Rose (2003), for example, suggests that job satisfaction is a product of the joint influences of work orientations and actual working conditions such as employment contract, work hours and monetary rewards. Brown and colleagues (2012) also argue that interpretations of self-reported job satisfaction data need to incorporate the influence of norms and expectations, potentially measured through work orientations, in order to achieve a better understanding of why workers report satisfaction (or dissatisfaction) with their jobs.

Clark (1997) is the first researcher who has explicitly addressed the gender job satisfaction differential from the work orientation perspective using large scale survey data. Clark has proposed four explanations. The first is that the gender job satisfaction gap reflects the overall differences in personal and job characteristics experienced by the two sexes. Second it has been suggested that self-reported job satisfaction may be associated with what one values in job rewards and there might be a gender pattern in 
what are desired that causes the difference in job satisfaction between men and women. Third, the fact that fewer women than men work suggests there may be a selection bias - only those women who are happy with their job remain in the labour market. Finally, job satisfaction is influenced not only by absolute income but also by relative income (which is one's expected income based on his or her personal and job characteristics). The latter form of income, according to Clark, plays an important role in shaping the gender satisfaction differential as women may have lower expectations of income than men. Using data from the 1991 British Household Panel Survey (BHPS), Clark has tested these hypotheses and found that the relative income thesis gained most empirical support, but none of them can fully account for the observed gender difference.

Hakim $(1991,2000)$ is another researcher who has written extensively on the gender pattern in work attitudes. She argues that there are two groups of women in the labour market - full time career women whose work orientations similar to those of men and women in part-time jobs who want to combine work and family. Despite the poor employment conditions, women part-timers often report higher levels of job satisfaction than full-time workers. Hakim suggests that this is because women parttimers usually prefer jobs with flexible work arrangements and the observed high job satisfaction is a consequence of the match between what they want and what the parttime jobs offer.

Hakim's thesis has been controversial and received many critical comments. One view is that Hakim has over-simplified the various needs that women part-timers have. Empirical evidence from qualitative research suggests that they are a highly varied 
group in terms of their skills, responsibilities and why they are engaged in part-time work (Procter and Padfield, 1999; Walters, 2005). Another criticism is that despite the high self-reported satisfaction, women part-timers are not genuinely happier with their jobs than full-time workers. Walters (2005) finds, for example, when followed up by in-depth interviews, some women who initially reported high job satisfaction in the survey have expressed contradicting views, complaining that they are constrained from pursuing a better career by domestic work and limited opportunities available to them. Therefore Walters argues that, instead of being truly satisfied, these women part-timers are 'making the best of a bad job'.

The question of whether women part-timers are genuinely satisfied with their jobs lies beyond the scope of this article. What is relevant here is that, despite the debate, there is a common view shared between the two camps. That is, there is a gender pattern in work orientations which is important for understanding women's responses to job satisfaction survey questions, differences being that Hakim thinks women's orientations reflect their preferences whereas Walters sees them as a consequence of structural constrains. Coincidently, some basic elements of these ideas can also be found in Clark's study. Hakim's 'preference' and Clark's 'selection' propositions, for example, both suggest that women are happier than men with their jobs because women can choose to stay out of the labour market or work part-time in a way most men cannot. Both 'grateful slaves' and 'making the best of a bad job' theses from Hakim and Walters can also be linked to Clark's 'relative income' hypothesis in a sense that women's subjective interpretation of job quality can be influenced by norms and expectations arising from family life and work experience (Brown et al., 2012). 
Although these studies have approached the gender pattern in job satisfaction with slightly different focuses, they all point to a same underlying explanatory variable, work orientations, in understanding how women evaluate their jobs. This presents a promising approach to the 'grateful slaves' paradox in that the work orientation thesis dismisses the arbitrary assumption adopted in previous research that men, women full-timers and women part-timers are homogeneous in what they seek, notably economic returns, from employment and links the gender job satisfaction gap to the differences in what they value in a job in the first place. Following this, women's greater job satisfaction would be the consequence of a better match between what they want and what their jobs offer than that for men. Previous research has been almost exclusively focused on the effects of the actual work conditions on job satisfaction and largely overlooked the influence from the 'orientations' side which may vary significantly across men, women full-timers and part-timers.

Unfortunately, with only a few exceptions (e.g., Clark, 1997), there has been limited effort to empirically investigate the relationship between work orientations and gender job satisfaction differential. There are two possible reasons. Firstly, research on job satisfaction in the past decade has been mainly conducted by economists and the primary concern has been around the impact of relative income on job satisfaction (see, for example, Clark, 1997; Sloane and Williams, 2000; Sousa-Poza and SousaPoza, 2003). Secondly, and more importantly, multiple-item measures of work orientations have not been widely implemented in large scale surveys until the mid1990s. For instance, the 1991 BHPS survey measures work orientations by asking respondents to choose only two aspects that they feel the most important about a job. 
This weak measure of work orientations may explain why although Clark has found work orientations differ significantly between men and women, they are not powerful predictors of the gender gap in job satisfaction. As Kalleberg (1977) has noted, using single ideal-type measure of work orientations is not very useful in analysing job satisfaction as it overlooks workers' valuation and experience of other dimensions of their job. Fortunately, much improved measures of work orientations have been available from recent employment surveys and the following analysis will use multiitem measures of work orientations from the 2006 Skills Survey to fully explore the relationships between work orientations and the gender job satisfaction differential.

\section{Data, measures and analytical strategies}

Data sources

The data for empirical investigations is from the 2006 Skills Survey. The 2006 Skills Survey is a nationally representative labour market survey that aims to provide comprehensive information on the employed workforce in the UK. The fieldwork was carried out between 2006 and 2007, covering 4,800 employed and self-employed individuals aged 20 to 65 with a gross response rate of 61.7 per cent. This survey provides rich information on a wide range of work attitudes, including multiple questions about work orientations and job satisfaction, which makes it an ideal data source for the proposed analysis. More details about the survey can be found in Felstead et al. (2007). 
The investigation will focus on employees only. Self-employed respondents are, therefore, removed from the analysis. Given that male part-timers only constitute 3 per cent of the sample and arguably have distinctive work orientations from those of male full-timers, they are also excluded from the analysis. The resulting final estimating sample contains 4110 individuals with 1926 males, 1324 female full-timers and 860 female part-timers. As there are 12.5 per cent of missing values in hourly pay, multiple imputation is employed to impute missing data for variables included in the models in order to retain the whole sample. ${ }^{2}$

Measures of job satisfaction

In the 2006 Skills Survey, the job satisfaction data is collected through a selfcompletion questionnaire and all response categories are clearly labelled. ${ }^{3}$ Respondents are asked to rate their overall job satisfaction by a question that reads, 'All in all, how satisfied would you say you are with your job?' A seven-point Likert scale is provided, running from 1 (completely satisfied) to 7 (completely dissatisfied). The order of the ranking is reversed in the analysis so that higher values indicate higher levels of job satisfaction. The distribution of the responses to this question is presented in Table 1.

TABLE 1 
Taking 5 to 7 as high levels of job satisfaction, Table 1 shows that the majority of the respondents are generally satisfied with their jobs. In our sample, 83.9 per cent of the male workers rated their overall job satisfaction 5 or above. The proportions are also very high for women -87.6 per cent of the women full-timers and 88.6 per cent of the women part-timers have similar job satisfaction scores.

In addition to overall job satisfaction, respondents are also asked to evaluate their satisfaction with a number of job facets in the same self-completion questionnaire. The question reads, 'I'm going to read out a list of various aspects of jobs, and for each one I'd like you to tell me, from this card, which number best describes how satisfied or dissatisfied you are with that particular aspect of your own present job'. Respondents were asked to rate on the same 1 to 7 scale fourteen job aspects, including: 1) promotion aspects, 2) pay, 3) relations with supervisor or manager, 4) job security, 5) opportunity to use abilities, 6) opportunity to use initiative, 7) ability and efficiency of management, 8) hours of work, 9) fringe benefits, 10) work itself, 11) amount of work, 12) variety in work, 13) training provided and 14) friendliness of people. The mean scores of these individual satisfaction facets, together with that of overall job satisfaction, are provided in Table 2.

\section{TABLE 2}

One-way ANOVA analysis has been carried out to test the equality of these job satisfaction scores across three groups of workers. The results show that there are significant variations in the mean levels of job satisfaction facets across men, women full-time and part-time workers with the only exception of pay and opportunity to use 
initiative. With respect to overall job satisfaction, the analysis has also found that men have the lowest score whereas women part-timers are the most satisfied group and such differences are statistically significant. These results have once again confirmed previous research findings that women are more satisfied with their jobs than men.

Measures of work orientations

Work orientations are measured by asking respondents to evaluate the importance of fifteen different job aspects when they look for a job. The question reads, 'I am going to read out a list of some of the things people may look for in a job and I would like you to tell me how important you feel each is to you'. The list of job aspects include: 1) good promotion prospects; 2) good pay; 3) good relations with your supervisor or manager; 4) a secure job; 5) a job where you can use your initiative; 6) work you like doing; 7) convenient hours of work; 8) choice in your hours of work; 9) the opportunity to use your abilities; 10) good fringe benefits; 11) an easy workload; 12) good training provision; 13) good physical working conditions; 14) a lot of variety in the type of work; 15) friendly people to work with. The response scale in the surveys is: '1) essential; 2) very important; 3) fairly important; and 4) not very important.' The scale is reversed so that a high score indicates a high level of importance. The mean scores of work orientations measures are presented in Table 3.

TABLE 3 
A similar one-way ANOVA test has been performed and the results show that there are significant variations in all work orientations measures across men, women fulltimers and part-timers. Specifically, compared to women full-timers, men are more likely to value pay, and when compared to women part-timers, they place more emphasis on promotion, pay, opportunities to use initiative and abilities, fringe benefits and variety in work. Women, on the whole, value relations with supervisor or manager, work they like doing, convenient work hours, choice in hours of work, physical working conditions and friendly people to work with. In addition to these gender stereotypes, there is considerable heterogeneity within the female workforce. Except for good relations with supervisor or manager, good physical work conditions and friendly people, there is a significant gap in all other work orientations measures between women full-timers and part-timers.

In order to achieve a parsimonious description, the work orientations items are submitted to a Confirmatory Factor Analysis. The CFA model developed is presented in Figure $1 .^{4}$

\section{FIGURE 1}

Five latent orientations variables, displayed by ovals, are included in the CFA model, which are intrinsic, extrinsic, effort, future and human orientations. Intrinsic orientations refer to the importance attached to the inherent interest of the job. Extrinsic orientations focus on the instrumental returns from the job. Effort and future orientations concern exertion and career development aspects of the job. Finally, human orientations are concerned with interpersonal relationships at the workplace. In 
addition to these five orientations, the measurement error that could mediate the correlations between the observed measures and latent variables is also controlled for in the model. Mills (2007) has noted two typical sources of measurement error in CFA which include 'methodological artifacts' and 'common content'. The first error is likely to occur where survey questions are arranged in the same sequence throughout the interviews while the second arises when two items have similar content which cannot be fully explained by the dependence on the same latent variable or the correlation between different latent variables. In order to control for these, error correlations are included when there is a plausible case for the two error sources.

The model fit statistics suggest that this work orientations model fits the data reasonably well. The mean root mean-squared error approximation (RMSEA) indices of the CFA model from five imputed datasets is 0.065 . Based on these results, five scales of work orientations are constructed by taking the mean of the items pertaining to a dimension for further analysis. ${ }^{5}$

Control variables

The analysis also includes a number of control variables. Clark (1997) suggests that relative income is an important determinant of job satisfaction. ${ }^{6}$ In addition, he also finds that there is a U-shape relationship between age and job satisfaction (Clark, 1996). Meng (1990) suggests that job satisfaction is associated with union status. Bender et al. (2005) find that the gender segregation at workplace also influences how one feels about their job. Other potential influences include occupational class, job 
contract type, marital status (Gorman, 2000), establishment size, industry and sector. Descriptive statistics of the variables used in the models is presented in Table 4.

\section{TABLE 4}

\section{Analytical strategies}

In empirical work, job satisfaction is typically analysed by ordered probit models, based on the assumption that the observed satisfaction ratings reflect the intervals where the latent continuous job satisfaction variable falls. This ordered probit job satisfaction model is as follows:

$J S_{i}^{*}=X_{i} \beta+\varepsilon_{i}$

$J S_{i}=k, \mu_{k}<J S_{i}^{*}<\mu_{k+1}$

where $J S^{*}$ is unobserved continuous job satisfaction, $X$ is a vector of exogenous variables, $J S$ is observed job satisfaction, $k$ is the number of categories that $J S$ falls into and $\mu$ is the estimated intercept term.

The analysis estimates three ordered probit models. Firstly a basic job satisfaction model will be developed with only female employment status dummies (female fulltimer and part-timer) and control variables included. Estimating this model will reveal the extent to which women are more satisfied with their jobs than men when personal and organisational characteristics are taken into account. The coefficients of these two 
female employment status dummies will serve as the baseline for cross-model comparisons by establishing the 'raw' gender job satisfaction differential. Work orientations variables will be introduced in the second model. This allows us to investigate the extent to which the observed gender gap in job satisfaction can be accounted for by work orientations, assuming that the effects of work orientations on overall job satisfaction are constant across men, women full-timers and part-timers. Finally a more flexible model will be fitted to include the interaction effects of work orientations and female employment status. This model allows effects of work orientations on job satisfaction to vary across these three groups of workers.

\section{Model estimation results}

The empirical investigation estimates three ordered probit models. The results are reported in Table 5.

\section{TABLE 5}

Model 1 shows that compared to men, women, either in full-time or part-time employment, are likely to report higher levels of overall job satisfaction, even after controlling for a wide range of individual and organisational factors. This confirms the initial findings from the ANOVA analysis that women are more satisfied with their jobs than men. The size of the coefficients of the female employment dummies also confirms that women part-timers have the highest level of job satisfaction among the three groups. These coefficients will be used as the benchmark against which the 
results of the following two models will be compared to assess the degree to which work orientations can account for the gender gap in job satisfaction.

Model 2 tests the effects of work orientations on job satisfaction, assuming they are constant across all workers. Five work orientations variables derived from the CFA are included in this model. The results in Table 5 suggest that work orientations are closely associated with job satisfaction. The coefficients of intrinsic, extrinsic, effort and human orientations are significant at the 0.05 level and future orientations 0.1 level, which seems to support the argument that individuals tend to engage in jobs where their work related needs are satisfactorily met.

Despite the highly significant effects of work orientations, the gender gap in job satisfaction persists. The coefficients of the two female employment status dummies are still sizeable and highly significant. Compared to Model 1, there is a small reduction in the difference in job satisfaction between men and women full-timers whereas the gap has even increased slightly between men and women part-timers. This suggests that although work orientations are strongly associated with job satisfaction, they do not contribute much to explaining the gender gap in job satisfaction when their effects are assumed to be constant across men, women fulltimers and part-timers.

The third model allows the effects of work orientations on job satisfaction to vary across the three groups by introducing interaction terms between female employment status and work orientations. As can be seen from Model 3, some of these interactive effects turn out to be highly significant. Women part-timers differ significantly from 
men in the effects of all work orientations on job satisfaction. The pattern for women full-timers is more similar to that of men. Compared to men, women full-timers do not differ substantially in extrinsic or future orientations and only marginally in effort orientations. They do, however, differ in intrinsic and human orientations. Most importantly, comparing the coefficients of the female employment status dummies to Model 1 shows that the gender difference in job satisfaction has been almost eliminated after these interaction effects are included. This is fully in line with the expectation that if heterogeneity in work orientations can account for the gender job satisfaction gap.

In addition to accounting for the gender job satisfaction differential, the analysis also reveals that different work orientations vary in the way they influence job satisfaction. When the effects are assumed to be constant across all workers (Model 2), intrinsic, future and human orientations are positively related to job satisfaction. This suggests that workers who place stronger emphasis on intrinsic job rewards, future development opportunities and good workplace relations are likely to report higher levels of job satisfaction. By contrast, the influences of extrinsic and effort work orientations on job satisfaction are negative, suggesting that the more workers value extrinsic or effort aspects of a job, the less likely they will be satisfied with their job. Moreover, the results show that intrinsic orientation is the most powerful predictor of overall job satisfaction among the five orientations variables, which is consistent with the vast body of empirical evidence that job satisfaction is mainly driven by intrinsic job components (Borzaga and Tortia, 2006; Huang and Van de Vliert, 2003). 
The final model (Model 3) further indicates that there is significant variation in how orientations influence job satisfaction when their effects are allowed to vary between men and women. Everything else being equal, while holding intrinsic orientations leads to positive feelings about one's job for both men and women, men are likely to report higher job satisfaction than women with similar levels of intrinsic orientations. By contrast, possessing similar levels of human orientations brings more happiness at work to women than it does to men. Extrinsic orientations are similar to human orientations, except their effects are negative. With regards to effort orientations, while the generally negative effect is observed for all workers, it appears less strong for women part-timers. Finally, men and women who value future-related job rewards are likely to report higher job satisfaction, although the effect is less strong for women part-timers. To further illustrate how work orientations affect job satisfaction across different groups of workers, separate OLS models are estimated on men, women fulltimer and women part-timer sub-samples to provide more easily interpretable coefficients. The results are summarised in Table 6 .

\section{TABLE 6}

While the divergence between men and women part-timers may be understood from different life goals (Hakim, 1991, 2000), the reasons why women full-timers differ from men in the way work orientations shape their job satisfaction have been less extensively discussed in the literature. Some further analysis suggests that these may be related to life-cycle and family responsibilities associated with gender role norms. In the sub-sample of men and women full-timers, the smaller effect of intrinsic orientations on job satisfaction is only significant for women in their middle ages. 
This is in line with the work-family conflict literature which suggests that women are more likely to experience declined interests towards work than men due to increased family roles after they enter this stage of life (Frome et al., 2006; Georgellis et al., 2012). Moreover, the additional positive effect of human orientations is found to be particularly strong among those women in prime reproductive ages. This could be that women in full-time jobs place more emphasis on workplace relations in order to facilitate informal support provision from supervisors and colleagues to help cope with conflicts between work and childcare (Behson, 2002; Brunetto et al., 2010).

\section{Conclusions}

This article has sought to answer the question of why women are more satisfied with their jobs than men. The central argument of this article has been that men and women differ in what they seek from employment and this could account for the observed gender job satisfaction differential. In other words, the 'grateful slaves' paradox arises when we fail to understand women's orientations to work and arbitrarily assume they look for similar rewards from employment as most men do. To empirically test this hypothesis, the study has drawn on data from the 2006 Skills Survey to analyse the gender gap in job satisfaction from the work orientations perspective.

The analysis has started with examining the gender difference in job satisfaction. Similar to many previous studies, the ANOVA analysis has found that women, either in full-time or part-time jobs, report higher levels of satisfaction than men. In addition, 
the analysis has also found that women part-timers have the highest levels of job satisfaction, followed by women full-timers and men.

Despite the divergence on whether work orientations reflect women's preferences or constrained choices, it has been suggested that women's distinctive work orientations play a key role in shaping their job satisfaction. The analysis clearly supports the view that work orientations differ significantly between men and women. It has been found that men are more likely to value extrinsic and intrinsic job rewards whereas women generally place more emphasis on social relations and flexible work hours. The analysis has also revealed that there is substantial heterogeneity in work orientations within the female workforce. Women full-timers and part-timers differ in almost every aspect except that they attach similar levels of importance to physical working conditions and workplace relationships.

Three ordered probit models have been developed to investigate if the heterogeneity in work orientations can explain the gap in job satisfaction between men and women. A baseline job satisfaction model includes only control variables. The results of this model have confirmed that women, either in full-time or part-time jobs, are indeed more satisfied with their jobs than men. The second model includes work orientations to explain job satisfaction, assuming their effects to be constant among men, women full-timers and part-timers. After intrinsic, extrinsic, effort, future and human orientations are entered into this model, all except future orientations turn out to be highly significant, which suggests work orientations are indeed important explanatory variables behind job satisfaction as suggested by prior research. However, the gap between men and women full-timers or part-timers remains largely unexplained. 
Previous work from economists and sociologists suggests that the effects of work orientations on job satisfaction may vary according to gender and employment status. Holding similar levels of extrinsic orientations, for example, might have quite different impact on job satisfaction between men and women full-timers or part-timers. To test this, interaction effects between work orientations and female employment status are introduced to the final model and the results suggest once the effects of orientations are allowed to vary between groups, the gender job satisfaction differential is largely accounted for. Not only have the coefficients of both female employment status dummies become insignificant, their magnitudes have shrunk dramatically as well.

Regarding how work orientations influence job satisfaction, the analysis suggests that those who value intrinsic, future or human job rewards are likely to report higher levels of job satisfaction whereas those who emphasize extrinsic or effort aspects of a job are likely to be less satisfied with their job, everything else being equal. Moreover, the analysis has also revealed some evidence that supports Hakim's female heterogeneity thesis. It has been found that women part-timers differ from men in intrinsic, effort, future and human orientations in terms of their effects on job satisfaction whereas women full-timers are more similar to men with the exception of intrinsic and human orientations.

One issue this article has not fully explored but deserves further attention is the impact of life-cycle on work orientations and job satisfaction. It is desirable because it could be argued that the significant relationship between work orientations and job satisfaction is a consequence of stage of life-cycle, independent of job itself. Women, 
for example, may hold 'dynamic' work orientations and change jobs due to various constraints over life-cycle. Preliminary analysis of the data has shown that women in prime reproductive ages are more likely to value workplace relations which could be interpreted as a means to cope with the conflicts between work and childcare through collegial support.

Although our analysis has shown that the difference in job satisfaction between men and women can be understood from a work orientations perspective, the crosssectional setting of the analysis will inevitably invite further comments. The nature of the cross-sectional data has restricted the analysis to assessing correlations instead of causations between work orientations and job satisfaction. Also, although we have explored how work orientations may help account for gender job satisfaction differential, the data does not allow for further exploration of some important questions such as why do women's orientations differ from those of men that lie at the core of the Hakim debate. These patterns could be due to gender norms such as women valuing workplace relations in order to get collegial support to cope with care responsibilities. It could also be argued women's emphasis on human factors might reflect the sex segregation in the labour market. For example, women's concentration on the service sector jobs may lead to increased importance of human factors in their orientations to work. Finally, the analysis also potentially suffers from unobserved heterogeneity. It cannot be ruled out that the observed gender satisfaction difference is caused by the factors that are not measured in the survey. These limitations call for future research to employ panel designs to offer stronger causal evidence on work orientations and their relationships with job satisfaction. 
In conclusion, the analysis has confirmed that the men and women differ in their orientations to work and this helps explain the gender pattern in job satisfaction. This lends support to Goldthorpe et al.'s (1968) argument some forty years ago that it would be helpful for analysis of work attitudes and behaviour to start with workers' needs and wants in their job rather than with the general assumption that they seek similar rewards from employment. A richer account of how work attitudes and behaviour develop, therefore, can be achieved if analytical frameworks take individuals' work orientations into consideration. 
Notes:

1. 'Work values' is another term often used interchangeably with 'work orientations' (e.g., Clark, 1997; Kalleberg, 1977). Despite the similarities, they are two distinctive concepts and should not be treated synonymous in use. Work values are general knowledge structure about what is good or desirable in work (Nord et al., 1990) whereas 'work orientations' are desirability of work features derived from one's value system. As such, 'work values' is a more abstract concept and can be viewed as the foundation from which work orientations are developed. Work values are relatively stable whereas work orientations can change rapidly in response to changes in work and private life (Brown et al., 2012).

2. The multiple imputation was performed by using the R package 'Amelia II' developed by Honaker et al. (2011). Five imputed datasets are produced for the data analysis.

The imputed datasets were analysed separately. The combined inferences from imputed datasets were drawn through the following way. Let $\hat{\theta}_{j}$ and $W_{j}$ be the point and variance estimates of a parameter from the $j$ th imputed dataset, $j=1,2, \ldots, m$. The point estimate of the parameter from multiple imputations is the average of the $m$ complete data estimates:

$$
\bar{\theta}=\frac{1}{m} \sum_{j=1}^{m} \hat{\theta}_{j} .
$$


The variance estimate from multiple imputations is approximately the sum of withinimputation variance, denoted as $\bar{W}$, and between-imputation variance, denoted as $B$ :

$$
T=\bar{W}+\left(1+\frac{1}{m}\right) B
$$

where

$$
\begin{aligned}
& \bar{W}=\frac{1}{m} \sum_{j=1}^{m} W_{j} \\
& B=\frac{1}{m-1} \sum_{j=1}^{m}\left(\hat{\theta}_{j}-\bar{\theta}\right)^{2} .
\end{aligned}
$$

3. Conti and Pudney (2011) identify two sources of response error that can inflate gender differences in self-reported job satisfaction in the survey setting. First, they find when the categories in the response scale are only partially labelled, women are likely to give higher job satisfaction scores than men. Second, women tend to report higher job satisfaction in an oral interview situation than men whereas this bias is not significant through the self-completion questionnaire.

4. This model is similar to Mills' (2007) job satisfaction CFA model.

5. The RMSEA index estimates the model fit relative to a saturated model in the population. A RMSEA index of 0.07 or lower is generally taken as a good fit to the data (Steiger, 2007).

The coefficients of the work orientations CFA model are reported in the following table: 


\section{TABLE 7}

Alternative method of scaling has been considered. Work orientations scales have been also constructed using factor score scaling which takes into account the weight each individual orientation items contribute to the scales. The results suggest this scaling method yielded very similar results to those from average scaling.

6. A standard human capital wage equation, which includes education, market experience and market experience squared, is used to generate 'relative income'. 


\section{References}

Anderson, D. J. (2001). "Race, Gender, and Discrimination at Work", Industrial \& Labor Relations Review, 54: 375-6.

Asadullah, M. N. and Fernádez, R. M. (2008). "Work-Life Balance Practices and the Gender Gap in Job Satisfaction in the UK: Evidence from Matched EmployerEmployee Data.", No. 3582, IZA Discussion paper.

Behson, S. J. (2002). "Coping with family-to-work conflict: The role of informal work accommodations to family", Journal of Occupational Health Psychology, 7: $324-41$.

Bender, K. A., Donohue, S. M. and Heywood, J. S. (2005). "Job satisfaction and gender segregation", Oxford Economic Papers, 57: 479-96.

Bennett, R. (1974). "Orientation to Work and Some Implications for Management", The Journal of Management Studies, 11: 149-62.

Borzaga, C. and Tortia, E. (2006). "Worker Motivations, Job Satisfaction, and Loyalty in Public and Nonprofit Social Services", Nonprofit and Voluntary Sector Quarterly, 35: 225-48.

Brown, A., Charlwood, A. and Spencer, D. (2012). "Not all that it might seem: why job satisfaction is worth studying despite it being a poor summary measure of job quality", Work, Employment and Society, 26: 7-18.

Brown, R., Curran, M. and Cousins, J. (1983). "Changing Attitudes to Employment?" Research Paper No. 40, London: Department of Employment. 
Brunetto, Y., Farr-Warton, R., Ramsey, S. and Shakloc, K. (2010). "Supervisor relationships and perceptions of work-family conflict', Asia Pacific Journal of Human Resources, 48: 212-32.

Clark, A., Oswald, A. and Warr, P. (1996). "Is Job Satisfaction U-Shaped in Age?", Journal of Occupational and Organizational Psychology, 69: 57-81.

Clark, A. E. (1997). "Job Satisfaction and Gender: Why Are Women So Happy at Work?", Labour Economics, 4: 341-72.

Conti, G. and Pudney, S. (2011). "Survey design and the analysis of satisfaction", The Review of Economics and Statistics, 93: 1087-93.

Curtice, J. (1993). "Satisfying Work, If You Can Get It." in Brook, L., Roemer, J. and Dowds, L. (ed.). International Social Attitudes: The 10th BSA Report. Dartmouth: Aldershot.

Darity, W. A. and Mason, P. L. (1998). "Evidence on Discrimination in Employment: Codes of Color, Codes of Gender", Journal of Economic Perspectives, 12: 6390.

Dex, S. (1998). Women's Attitudes Towards Work. London: Macmillan.

Doorewaard, H., Hendrickx, J. and Verschuren, P. (2004). "Work Orientations of Female Returners", Work, employment and society, 11: 95-115.

Duncan, C. and Loretto, W. (2004). "Never the Right Age? Gender and Age-Based Discrimination in Employment", Gender Work and Organization, 11: 95-115. 
Felstead, A., Gallie, D., Green, F. and Zhou, Y. (2007). Skills at Work: 1986-2006. Oxford: SKOPE.

Frome, P. M., Alfeld, C. J., Eccles, J. S. and Barber, B. L. (2006). 'Why Don't They Want a Male-Dominated Job? An investigation of young women who changed their occupational aspirations', Educational Research and Evaluation, 12: $359-72$.

Gallie, D. (2007). "Welfare Regimes, Employment Systems and Job Preference Orientations", European Sociological Review, 23: 279-93.

George, J. M. and Jones, G. R. (1997). "Experiencing Work: Values, Attitudes, and Moods", Human Relations, 50: 393-416.

Georgellis, Y., Lange, T. and Tabvuma, V. (2012) "The impact of life events on job satisfaction", Journal of Vocational Behavior, 80: 464-73.

Goldthorpe, J., Lockwood, D., Bechhofer, F. and Platt, J. (1968). The Affluent Workers: Industrial Attitudes and Behaviour. Cambridge: Cambridge University Press.

Gorman, E. H. (2000). "Marriage and Money - The Effect of Marital Status on Attitudes Toward Pay and Finances", Work and Occupations, 27: 64-88.

Hakim, C. (1991). "Grateful Slaves and Self-Made Women: Fact and Fantasy in Women's Work orientations", European Sociological Review, 7: 101-21.

Hakim, C. (2000). Work-Lifestyle Choices in the 21st Century: Preference Theory. Oxford: Oxford University Press. 
Honaker, J., King, G. and Blackwell, M. (2011). "Amelia II: A Programme for Missing Data", http://gking.harvard.edu/amelia/.

Huang, X. and Van de Vliert, E. (2003). "Where Intrinsic Job Satisfaction Fails to Work: National Moderators of Intrinsic Motivation", Journal of Organizational Behavior, 24: 159-79.

Kalleberg, A. (1977). "Work orientations and Job Rewards: A Theory of Job Satisfaction", American Sociological Review, 42: 124-43.

Meng, R. (1990). "The Relationship Between Unions and Job-Satisfaction", Applied Economics, 22: 1635-48.

Mills, C. (2007). "Job Quality, Satisfaction and Expectations." Sociology Working Paper, Paper Number 2007-06: University of Oxford.

Procter, I. and Padfield, M. (1999). "Work orientations and women's work: A critique of Hakim's theory of the heterogeneity of women", Gender, Work and Organization, 6: 152-62.

Rose, M. (2003). "Good Deal, Bad Deal? Job Satisfaction in Occupations", Work, Employment and Society, 17: 503-30.

Rose, M. (2007). "Work attitudes - A sociological review", Paper presented at the ESRC Seminar on Work Attitude Measures: University of Bath.

Sloane, P. J. and Williams, H. (2000). "Gob Satisfaction, Comparison Earnings, and Gender", Labour, 14: 473-502. 
Sousa-Poza, A. and Sousa-Poza, A. A. (2003). "Gender differences in job satisfaction in Great Britain, 1991-2000: permanent or transitory", Applied Economic Letters, 10 (11): 691-4.

Steiger, J.H. (2007), "Understanding the limitations of global fit assessment in structural equation modeling", Personality and Individual Differences, 42 (5), 893-8.

Townsend, P. (1979). Poverty in the United Kingdom. London: Allen Lane.

Walters, S. (2005). "Making the Best of a Bad Job? Female Part-Timers' Orientations and Attitudes to Work", Gender, Work and Organization, 12: 193-216. 


\section{Tables and figures}

Table 1 Levels of overall job satisfaction (\%)

\begin{tabular}{lrrr}
\hline \hline Overall job satisfaction & Male & Female full-timer & Female part-timer \\
\hline 1 (lowest) & 1.2 & 0.8 & 1.0 \\
2 & 1.8 & 2.1 & 1.6 \\
3 & 6.4 & 4.3 & 3.3 \\
4 & 6.6 & 5.1 & 5.4 \\
5 & 36.1 & 35.3 & 31.3 \\
6 & 36.6 & 37.2 & 37.1 \\
7 (highest) & 11.2 & 15.1 & 20.2 \\
Total & 100.0 & 100.0 & 100.0 \\
$N$ & 1926 & 1324 & 860 \\
\hline
\end{tabular}

Note: Mean proportions of the five imputed datasets are reported.

Table 2 Mean levels of job satisfaction facets and overall job satisfaction

\begin{tabular}{|c|c|c|c|}
\hline Job satisfaction facet & Male & Female full-timer & Female part-timer \\
\hline Promotion* & 4.47 & 4.61 & 4.47 \\
\hline Pay & 4.62 & 4.57 & 4.58 \\
\hline Relations with supervisor/manager* & 5.36 & 5.48 & 5.64 \\
\hline Job security* & 5.33 & 5.45 & 5.45 \\
\hline To use abilities* & 5.48 & 5.59 & 5.50 \\
\hline To use initiative & 5.65 & 5.70 & 5.60 \\
\hline Ability/efficiency of management* & 4.62 & 4.83 & 5.04 \\
\hline Work hours* & 5.07 & 5.18 & 5.78 \\
\hline Fringe benefits* & 4.38 & 4.23 & 4.34 \\
\hline Work itself* & 5.40 & 5.53 & 5.60 \\
\hline Amount of work ${ }^{*}$ & 5.04 & 4.90 & 5.27 \\
\hline Variety in the work* & 5.39 & 5.53 & 5.47 \\
\hline Training provided ${ }^{*}$ & 4.88 & 5.08 & 5.04 \\
\hline Friendliness of people* & 5.81 & 5.94 & 6.00 \\
\hline Overall job satisfaction* & 5.29 & 5.44 & 5.56 \\
\hline
\end{tabular}


Table 3 Mean levels of work orientations

\begin{tabular}{lrrr}
\hline \hline Work orientations & Male & Female full-timer & Female part-timer \\
\hline Good promotion* $^{*}$ & 2.44 & 2.49 & 2.21 \\
Good pay* $^{*}$ & 3.15 & 3.06 & 2.94 \\
Good relations with supervisor/manager* $^{*}$ & 3.03 & 3.24 & 3.26 \\
Secure job* & 3.19 & 3.23 & 3.14 \\
To use initiative* & 3.12 & 3.18 & 3.04 \\
Work like doing* & 3.32 & 3.49 & 3.40 \\
Convenient work hours* & 2.59 & 2.85 & 3.23 \\
Choice in work hours* & 2.24 & 2.47 & 2.80 \\
To use abilities* & 3.16 & 3.26 & 3.05 \\
Good fringe benefits* & 2.34 & 2.30 & 2.20 \\
Easy workload* & 1.80 & 1.79 & 1.94 \\
Good training provision & 2.72 & 2.87 & 2.78 \\
Good physical working conditions $^{*}$ & 2.85 & 2.99 & 2.98 \\
A lot of variety in work & 2.82 & 2.96 & 2.72 \\
Friendly people* $^{*}$ & 3.08 & 3.28 & 3.30 \\
\hline
\end{tabular}

Note:

1. Mean scores of work value orientations of the five imputed datasets are reported.

2. ${ }^{*}$ indicates $\mathrm{p}<0.05$ in one-way ANOVA analysis. 
Table 4 Descriptive statistics

\begin{tabular}{|c|c|c|}
\hline & Mean & $\overline{\text { S.D. }}$ \\
\hline Overall job satisfaction & 5.40 & 1.18 \\
\hline Age & 41.67 & 11.18 \\
\hline Intrinsic work orientations & 1.87 & 0.56 \\
\hline Extrinsic work orientations & 2.31 & 0.72 \\
\hline Effort work orientations & 2.64 & 0.68 \\
\hline Future work orientations & 2.17 & 0.61 \\
\hline Human work orientations & 1.83 & 0.59 \\
\hline Hourly pay & 11.78 & 12.37 \\
\hline Relative hourly pay & 10.36 & 2.92 \\
\hline \multicolumn{3}{|l|}{ Gender employment status } \\
\hline Male* $^{*}$ & 0.47 & 0.50 \\
\hline Female full-timer & 0.32 & 0.47 \\
\hline Female part-timer & 0.21 & 0.41 \\
\hline \multicolumn{3}{|l|}{ Job contract type } \\
\hline Seasonal/Temping/Casual* & 0.02 & 0.13 \\
\hline Fix-term & 0.03 & 0.16 \\
\hline Permanent & 0.96 & 0.20 \\
\hline \multicolumn{3}{|l|}{ Occupational class } \\
\hline Managers** & 0.15 & 0.36 \\
\hline Professionals & 0.13 & 0.33 \\
\hline Associate professionals & 0.16 & 0.36 \\
\hline Administrative \& secretarial & 0.13 & 0.34 \\
\hline Skilled trades & 0.09 & 0.29 \\
\hline Personal services & 0.09 & 0.28 \\
\hline Sales & 0.07 & 0.25 \\
\hline Plant \& machine operatives & 0.08 & 0.27 \\
\hline Elementary & 0.10 & 0.31 \\
\hline \multicolumn{3}{|l|}{ Industry } \\
\hline Primary* & 0.01 & 0.11 \\
\hline Manufacturing & 0.15 & 0.36 \\
\hline Construction \& services & 0.83 & 0.37 \\
\hline \multicolumn{3}{|l|}{ Sector } \\
\hline Private* & 0.62 & 0.49 \\
\hline Public \& NGO & 0.38 & 0.49 \\
\hline \multicolumn{3}{|l|}{ Marital status } \\
\hline Married* ${ }^{*}$ & 0.54 & 0.50 \\
\hline Cohabited & 0.12 & 0.33 \\
\hline Single & 0.21 & 0.41 \\
\hline Widowed & 0.02 & 0.14 \\
\hline Separated/divorced & 0.11 & 0.31 \\
\hline \multicolumn{3}{|l|}{ Education } \\
\hline No qualifications* & 0.11 & 0.31 \\
\hline Elementary & 0.10 & 0.30 \\
\hline Lower secondary & 0.21 & 0.41 \\
\hline Upper secondary & 0.22 & 0.42 \\
\hline Degree or above & 0.36 & 0.48 \\
\hline \multicolumn{3}{|l|}{ Establishment size } \\
\hline $1^{*}$ & 0.02 & 0.14 \\
\hline $2-24$ & 0.31 & 0.46 \\
\hline $25-99$ & 0.26 & 0.44 \\
\hline $100-499$ & 0.24 & 0.42 \\
\hline 500 or more & 0.17 & 0.37 \\
\hline \multicolumn{3}{|l|}{ Gender segregation } \\
\hline Similar job undertaken all by men* & 0.13 & 0.33 \\
\hline Similar job undertaken mainly by men & 0.22 & 0.42 \\
\hline Similar job undertaken equally by men and women & 0.31 & 0.46 \\
\hline Similar job undertaken mainly by women & 0.26 & 0.44 \\
\hline Similar job undertaken all by women & 0.08 & 0.27 \\
\hline \multicolumn{3}{|l|}{ Union status } \\
\hline Union member* & 0.33 & 0.47 \\
\hline Non-union member & 0.67 & 0.47 \\
\hline
\end{tabular}

Note: 1. Means from the five imputed datasets are reported.

2. ${ }^{*}$ indicates reference category in the ordered probit analysis. 
Table 5 Overall job satisfaction and work orientations: Ordered probit estimates

\begin{tabular}{|c|c|c|c|}
\hline & Model 1 & Model 2 & Model 3 \\
\hline \multicolumn{4}{|l|}{ Gender employment status } \\
\hline Female full-timer & $0.132(0.034)^{* *}$ & $0.111(0.034)^{* *}$ & $-0.003(0.005)$ \\
\hline Female part-timer & $0.226(0.037)^{* *}$ & $0.258(0.037)^{* *}$ & $0.008(0.005)$ \\
\hline \multicolumn{4}{|l|}{ Work orientations } \\
\hline Intrinsic orientations & & $0.257(0.037)^{* *}$ & $0.336(0.032)^{* *}$ \\
\hline Extrinsic orientations & & $-0.083(0.030)^{* * *}$ & $-0.064(0.026)^{*}$ \\
\hline Effort orientations & & $-0.131(0.028)^{* *}$ & $-0.166(0.026)^{* * *}$ \\
\hline Future orientations & & $0.065(0.037)^{\dagger}$ & $0.107(0.032)^{* *}$ \\
\hline Human orientations & & $0.182(0.033)^{* *}$ & $0.136(0.029)^{* *}$ \\
\hline \multicolumn{4}{|l|}{ Gender employment status*orientations } \\
\hline Female full-timer*Intrinsic orientations & & & $-0.182(0.027)^{* *}$ \\
\hline Female part-timer*Intrinsic orientations & & & $-0.104(0.021)^{* *}$ \\
\hline Female full-timer*Extrinsic orientations & & & $-0.029(0.035)$ \\
\hline Female part-timer*Extrinsic orientations & & & $-0.053(0.028)^{\dagger}$ \\
\hline Female full-timer*Effort orientations & & & $0.063(0.038)^{\dagger}$ \\
\hline Female part-timer*Effort orientations & & & $0.071(0.031)^{*}$ \\
\hline Female full-timer*Future orientations & & & $-0.015(0.022)$ \\
\hline Female part-timer*Future orientations & & & $-0.128(0.017)^{* * *}$ \\
\hline Female full-timer*Human orientations & & & $0.079(0.024)^{* *}$ \\
\hline Female part-timer*Human orientations & & & $0.093(0.018)^{* *}$ \\
\hline \multicolumn{4}{|l|}{ Control variables } \\
\hline Age & $-0.010(0.006)^{\dagger}$ & $0.001(0.007)$ & $0.000(0.007)$ \\
\hline $\mathrm{Age}^{2} / 1000$ & $0.186(0.083)^{*}$ & $0.065(0.088)$ & $0.082(0.087)$ \\
\hline Hourly pay & $0.202(0.034)^{* *}$ & $0.185(0.036)^{* * *}$ & $0.187(0.036)^{* * *}$ \\
\hline Relative hourly pay & $-0.403(0.015)^{* *}$ & $-0.479(0.014)^{* *}$ & $-0.481(0.015)^{* *}$ \\
\hline Fix-term contract & $0.336(0.011)^{* *}$ & $0.347(0.010)^{* *}$ & $0.343(0.010)^{* *}$ \\
\hline Permanent contract & $0.363(0.018)^{* *}$ & $0.394(0.017)^{* *}$ & $0.390(0.016)^{* *}$ \\
\hline Professional & $-0.014(0.042)$ & $-0.038(0.043)$ & $-0.039(0.043)$ \\
\hline Associate professionals & $-0.054(0.041)$ & $-0.050(0.041)$ & $-0.055(0.041)$ \\
\hline Administrative \& secretarial & $-0.142(0.042)^{* *}$ & $-0.093(0.043)^{*}$ & $-0.105(0.043)^{*}$ \\
\hline Skilled trades & $-0.024(0.046)$ & $0.013(0.046)$ & $0.005(0.047)$ \\
\hline Personal services & $-0.013(0.044)$ & $0.000(0.045)$ & $-0.005(0.043)$ \\
\hline Sales & $-0.254(0.027)^{* *}$ & $-0.196(0.028)^{* * *}$ & $-0.206(0.023)^{* * *}$ \\
\hline Plant \& machine operatives & $-0.067(0.043)$ & $0.009(0.043)$ & $0.015(0.035)$ \\
\hline Elementary & $-0.268(0.047)^{* *}$ & $-0.175(0.048)^{* *}$ & $-0.180(0.048)^{* *}$ \\
\hline Manufacturing & $-0.256(0.025)^{* *}$ & $-0.268(0.025)^{* *}$ & $-0.279(0.024)^{* *}$ \\
\hline Construction \& services & $-0.122(0.025)^{* *}$ & $-0.124(0.025)^{* *}$ & $-0.130(0.025)^{* *}$ \\
\hline Public \& NGO & $0.093(0.037)^{*}$ & $0.075(0.038)^{*}$ & $0.077(0.038)^{*}$ \\
\hline Establishment size 2-24 & $-0.251(0.029)^{* *}$ & $-0.266(0.029)^{* *}$ & $-0.266(0.029)^{* *}$ \\
\hline Establishment size 25-99 & $-0.421(0.029)^{* *}$ & $-0.431(0.029)^{* *}$ & $-0.432(0.029)^{* *}$ \\
\hline Establishment size $100-499$ & $-0.497(0.030)^{* *}$ & $-0.497(0.030)^{* *}$ & $-0.494(0.030)^{* *}$ \\
\hline Establishment size 500 or more & $-0.498(0.034)^{* *}$ & $-0.496(0.034)^{* *}$ & $-0.497(0.034)^{* *}$ \\
\hline Cohabited & $-0.185(0.050)^{* *}$ & $-0.228(0.051)^{* * *}$ & $-0.223(0.051)^{* *}$ \\
\hline Single & $-0.153(0.042)^{* *}$ & $-0.182(0.043)^{* *}$ & $-0.173(0.043)^{* *}$ \\
\hline Widowed & $0.087(0.003)^{* *}$ & $0.074(0.004)^{* *}$ & $0.081(0.003)^{* *}$ \\
\hline Separated/divorced & $-0.052(0.054)$ & $-0.074(0.054)$ & $-0.070(0.054)$ \\
\hline Job undertaken mainly by men & $-0.097(0.041)^{*}$ & $-0.104(0.041)^{*}$ & $-0.109(0.039)^{* * *}$ \\
\hline Job undertaken equally by men and women & $0.012(0.032)$ & $-0.003(0.032)$ & $-0.013(0.032)$ \\
\hline Job undertaken mainly by women & $0.032(0.032)$ & $-0.008(0.032)$ & $-0.015(0.033)$ \\
\hline Job undertaken all by women & $-0.029(0.040)$ & $-0.090(0.040)^{*}$ & $-0.096(0.040)^{*}$ \\
\hline Non-union member & $0.050(0.038)$ & $0.056(0.038)$ & $0.052(0.038)$ \\
\hline Residual Deviance & 11728.74 & 11577.67 & 11566.02 \\
\hline$N$ & 4110 & 4110 & 4110 \\
\hline
\end{tabular}


Table 6 Overall job satisfaction and work orientations by male, female full-timer and female part-timer: OLS estimates

\begin{tabular}{lrrr}
\hline \hline & Male & Female full-timer & Female part-timer \\
\hline Intrinsic orientations & $0.304(0.059)^{* *}$ & $0.099(0.074)$ & $0.212(0.089)^{*}$ \\
Extrinsic orientations & $-0.073(0.047)$ & $-0.049(0.058)$ & $-0.121(0.069)^{\dagger}$ \\
Effort orientations & $-0.198(0.044)^{* *}$ & $-0.144(0.055)^{* *}$ & $-0.109(0.072)$ \\
Future orientations & $0.122(0.057)^{*}$ & $0.041(0.075)$ & $-0.040(0.087)$ \\
Human orientations & $0.115(0.05)^{*}$ & $0.207(0.067)^{* *}$ & $0.179(0.086)^{*}$ \\
& & & \\
Adjusted $\mathrm{R}^{2}$ & 0.08 & 0.04 & 0.06 \\
$N$ & 1926 & 1324 & 860 \\
\hline
\end{tabular}

Note:

1. The same set of control variables as in the ordered probit models are included but not presented.

2. ${ }^{\dagger} \mathrm{p}<0.1,{ }^{*} \mathrm{p}<0.05,{ }^{* *} \mathrm{p}<0.01$.

Table 7 Confirmatory Factor Analysis model: Work orientations

\begin{tabular}{lc}
\hline \hline & Weight \\
\hline Intrinsic work orientations & 1.00 \\
$\quad$ To use initiative & 0.76 \\
Work like doing & 0.95 \\
To use abilities & 0.89 \\
A lot of variety in work & \\
Extrinsic work orientations & 1.00 \\
$\quad$ Good pay & 1.09 \\
Good fringe benefits & 0.83 \\
Good physical working conditions & \\
Effort work orientations & 1.00 \\
Convenient hours of work & 1.06 \\
Choice in work hours & 0.58 \\
Easy workload & 1.00 \\
Future work orientations & 0.63 \\
$\quad$ Good promotion & 0.82 \\
Secure job & \\
Good training provision & 1.00 \\
Human work orientations & 0.95 \\
$\quad$ Good relations with manager & \\
Friendly people &
\end{tabular}

Note: Mean coefficients from imputed datasets are reported. 


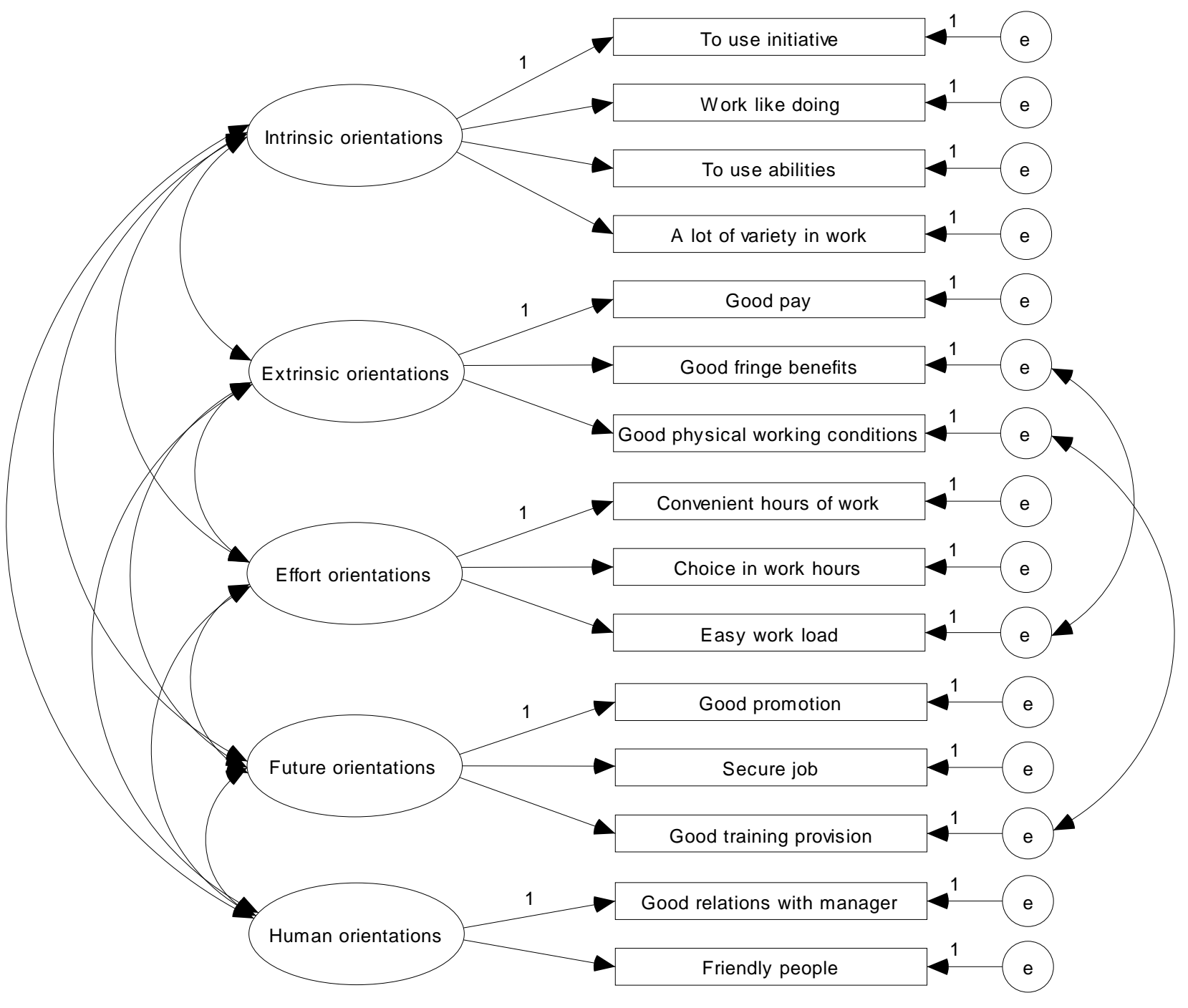

Figure 1 Confirmatory Factor Analysis: Work orientations 


\section{Acknowledgement:}

The author would like to thank Colin Mills, Duncan Gallie and three anonymous referees for their constructive feedback on earlier drafts of the article.

\section{Author contact:}

Address: Bain \& Company, 40 Strand, London WC2N 5RW, UK

Emal: $\underline{\text { min.zou@bain.com }}$

\section{Author bio:}

Min Zou holds a D.Phil. in Sociology from Nuffield College, Oxford. His research interests include labour markets, social stratification, China and quantitative methods. 